\title{
Risk Reporting Practices of Listed Companies: Cross- Country Empirical Evidence from the Auto Industry
}

\author{
- Jana Vychytilova, Orkhan Nadirov, Drahomira Pavelkova, Martin \\ Mikeska
}

\begin{abstract}
Prior literature has shown that corporate transparency is linked to a firm's competitiveness. The frequently noted vagueness and inadequacy of reported risk disclosures have been accompanied by calls for industry-specific studies. This paper aims to examine the disclosure informativeness of leading multinational automobile firms worldwide regarding firm-specific risks, namely company risk and company size. Applying a content analysis to examine the prevalent disclosure context in the automotive industry, we analyze and classify the annually reported risk statements of 34 multinationals quoted within the NASDAQ OMX Global Automobile Index. These corporations are headquartered in 10 countries, located in the U.S. as well as in the E.U. and in Asia. Based on an employed Wilcoxon signed rank test, our results show that automobile multinationals favor revealing fewer (more) forward-looking and bad-news risk disclosures as compared to past-looking and good-news risk statements. Our findings further indicate that bigger and riskier automobile multinationals do not reveal larger amounts of risk information. This finding is inconsistent with disclosure theory and provides insight into less complex risk reporting practices that affect investor perceptions of risk by omitting risk information. This paper also provides new empirical evidence regarding the association between company risk and corporate risk disclosing practices in the auto industry; our data show that company size did not play a significant role. With our concentration on explaining current risk reporting practices in the automotive sector, these results are robust with respect to firm-specific risk variables, thus the findings may prove usable for policy frameworks.
\end{abstract}

Keywords: risk disclosure, risk reporting, annual reports, content analysis, automotive industry, informativeness JEL Classification: G32, M42, O57

Received: May, 2020

1st Revision: October, 2020

Accepted: October, 2020

\section{INTRODUCTION}

The principles of risk, risk reporting, and risk management have recently attracted considerable attention as the world economy has become increasingly competitive (Lobo et al., 2019). Transparency is widely considered critical for individual firms as well as in terms of national com- 
petitiveness (Wyld, 2009). Corporate transparency in financial reporting refers essentially to disclosing risks in corporate annual reports (Kang \& Gray, 2019). The call for transparent corporate financial reporting is widely accepted by regulators worldwide as an important theme in economic-political debates in a global context (Transparency International, 2014; Kang \& Gray, 2019). This is due to the numerous recent corporate scandals which have been blamed on multinational firms hiding their risky and questionable operating and business activities. The most recent financial crisis has also raised the concern that mandatory disclosures also portray firm risk non-transparently (Badia et al., 2019). Consequently, the external pressure on companies to become more transparent toward their stakeholders and investors has increased (Manes-Rossi, 2018). Previous literature dedicated to disclosed risks in the annual reports of non-financial companies has usually been conducted within one country as a cross-industry study of companies listed within a particular stock market index. However, the ongoing call has not been heeded for broader risk disclosure studies. The studies which have been conducted have been found particularly lacking in terms of cross-country and industry-specific risk disclosure studies that could improve the overall perception of business risk reporting practices.

This paper seeks to begin to fill this knowledge gap as well as to supplement the existing risk reporting literature in other ways. First, this article adds to the relatively limited cross-country literature related to risk disclosure in the automotive industry (generally conducted only as panel studies within various industries, e.g., Campbell et al., 2014, Hope et al., 2016). Second, the explanation of the links between two firm-specific characteristics could enhance the understanding of the risk disclosing practices dedicated to the auto industry: i) a level of company size ii) the level of company risk. These two characteristics are evaluated in terms of quantity of iii) total iv) total financial v) and total non-financial disclosed risk statements in the 34 recent annual reports of the biggest and liquid automakers headquartered and listed in 10 countries, located in the U.S. as well as in the E.U. and in Asia. Third, this study explains the prevalent nature of the disclosed risk information, and fourth, sheds a degree of light on whether more i) monetary or non-monetary risk disclosures, ii) past or forward-looking risk disclosures, iii) and positive news or negative news risk disclosures are disclosed by automakers, with our results seeking to provide policy and practical implications. These findings may help accounting policymakers and academics broaden their understanding of risk reporting and educate financial statement users to consider the implications and act accordingly. The research goals of this paper are namely to i) test for a linkage between the level of company size and the volume of risk disclosure, ii) test for a relation between the level of company risk and the volume of risk disclosure, iii) examine the characteristics of the risk disclosure considering the type of risk, the proportion of good and bad news risk sentences, and time orientation. The automotive industry was chosen particularly for its large global economic footprint and for its global industry interconnectedness (International Monetary Fund, 2019; Vychytilová et al., 2019; World Bank, 2019). Furthermore, vehicles and car components are the world's fifth-largest exported goods, accounting for around 8 percent of global exports of goods in 2018 (International Monetary Fund, 2019; Vychytilová et al., 2019; World Bank, 2019). Further, the automotive sector is of current interest to policymakers since it contributes substantially to greenhouse gas emissions (Nadirov et al., 2020). 
The paper is organized as follows. Section 2 presents the theoretical framework and hypotheses. The research design is described in Section 3. The research results are presented in Section 4, and Section 5 concludes the paper with a review of the empirical findings and concluding remarks.

\section{THEORETICAL BACKGROUND AND HYPOTHESIS DEVELOPMENT}

Risk disclosure is information that explains particular corporate risks and the expected exposure of firms to current and future corporate performance scrutiny (Dey et al., 2018; Miihkinen, 2012). To express the risk disclosure context, risk disclosures in this study have been classified in line with prior studies (Abid \& Shaique, 2015; Linsley \& Shrives, 2006) as one of six types: financial risk, empowerment, operations risk, integrity risk, strategic risk, along with technology and information processing risk.

In this study, we focus on the risk disclosures of non-financial companies, while we exclude financial firms in accordance with prior studies on risk disclosure (Abid \& Shaique, 2015; Elshandidy et al., 2013; Elshandidy \& Shrives, 2016; Halbouni \& Yasin, 2016; Rodríguez Domínguez \& Gámez, 2014). Financial firms are excluded due to their distinct regulations, accounting practices and significantly different types of risk disclosures. Several papers have noted vagueness and inadequacy in reported risk disclosures (Abraham \& Shrives, 2014; Camfferman \& Wielhouwer, 2019; Elshandidy et al., 2018; Hope et al., 2016; Kim \& Yasuda, 2018; Linsley \& Shrives, 2006). Non-specific, generic, or merely descriptive risk management policy disclosures are considered by these studies as unhelpful in terms of identifying the risk profile of a business; these types of disclosures have long been criticized by stakeholders (Abraham \& Shrives, 2014; Camfferman \& Wielhouwer, 2019). Chiu et al. (2018) revealed that risk disclosure related to financial and idiosyncratic risk, a factor relevant in the credit market, can be especially helpful, as it allows credit investors to better understand and analyze the company's credit risk. Overall, reported risk disclosure studies tend to address risk disclosure informativeness (Abraham \& Shrives, 2014; Bao \& Data, 2014; Campbell et al., 2019; Filzen, 2015) and/or risk disclosure incentives (Bae et al., 2018; Campbell et al., 2014; Elshandidy \& Shrives, 2016; Hope et al., 2016). These indicators have practical consequences for investors, employees and clients, as they can facilitate the choice of which businesses to invest in (Gavana et al., 2017). An expanding field of studies on risk disclosure informativeness has focused primarily on exploring voluntary risk disclosure, mandatory risk disclosure (Filzen, 2015; Kravet \& Muslu, 2013), and aggregate disclosure (Abraham \& Shrives, 2014; Bao \& Datta, 2014; Linsley \& Lawrence, 2007). Aggregate disclosures are the main interest of the current study.

Prior risk disclosure literature on informativeness has mainly presented results in terms of measured dependent variables, i. e. words (Bao \& Datta, 2014; Campbell et al., 2014; Hope et al., 2016), sentences (Abraham \& Shrives, 2014; Elshandidy \& Neri, 2015; Elshandidy \& Shrives, 2016; Linsley \& Shrives, 2006; Ntim et al., 2013), or disclosure indexes (Dey et al., 2018; Hill \& Short, 2009; Taylor et al., 2010; Pivac et al., 2017). Our study adopts the sentence count approach. Previous risk disclosure studies have used manual (Abraham \& Cox, 2007; Abraham \& Shrives, 2014; Ntim et al., 2013) or automated (Bao \& Datta, 2014; Filzen, 2015; Kravet \& 
Muslu, 2013) content analysis to collect and analyze textual information. Elshandidy et al. (2018) pointed out that computerized content analysis is preferred for longitudinal studies (Dey et al., 2018; Ntim et al., 2013), while manual content analysis is frequently employed for a shorter time period, typically one year. Our study uses manual content analysis to collect and analyze sentences in the annual reports of a single year (for the limitations of content analysis, see Elshandidy et al. 2018).

"A comprehensive theory of discretionary disclosure which clearly identifies the determinants of disclosure does not yet exist" (Abraham \& Shrives, 2014, p. 2). However, research on risk disclosure refers generally in prior literature to various theories. Ranking among the frequently applied disclosure theories are agency theory (businesses disclose less information than is required because are monitored by shareholders; as is initially suggested by Jensen \& Meckling, 1976; and later frequently applied in prior disclosure papers such as Elshandidy et al., 2013), signaling theory (firms close less information than is required as a consequence of directors believing their company is better than others; as can be derived initially from Spence, 1973; and later was applied by Elshandidy et al., 2013), political costs hypothesis (firms close less voluntary information to exploit their image and divert unwanted scrutiny from policymakers, stakeholders, and media; as implicates initially from Watts \& Zimmerman, 1978), legitimacy theory and resource-based perspectives (Shocker \& Sethi, 1973; implying that firms disclose more to avoid suspicion of violations of company standards and to legitimize their past behavior to society; as later frequently discussed in prior disclosure studies such as Ntim et al., 2013). Whereas there is no consensus yet among scholars as to which theory dominates, thus a multi-theoretic approach is commonly considered to be suitable (Abraham \& Shrives, 2014; Abid \& Shaique, 2015). This study focuses on the hypotheses that are compatible with Linsley \& Shrives (2006) research and prior general disclosure studies frequently applying them (Abid \& Shaique, 2015; Dey et al., 2018). The hypotheses are generally dedicated to company size (size), company level of risk (level of risk), and disclosure context (economic sign, type of measure, and outlook sign). Our developed hypotheses are closely connected to corporate competitiveness, while more transparent businesses (revealing more risk disclosure) are willing to meet their competition head-on (Shivaani \& Agarwal, 2020).

\subsection{Size}

It is argued that larger firms can afford to reveal risk information because the proportionate cost will be less when compared to smaller companies (Hassan et al., 2006). However, there are contradictory results among the studies of the previous scholars. The prior literature (Abid \& Shaique, 2015; Alsaeed, 2006; Dey et al., 2018; Elshandidy \& Shrives 2016; Elshandidy et al., 2013; Elzahar \& Hussainey, 2012; Kurniawanto et al., 2017; Linsley \& Shrives, 2006; Marzouk, 2016; Miihkinen, 2012; Taylor et al., 2010) frequently provides evidence of a positive relation between the level of disclosure and company size. However, Halbouni \& Yasin (2016) found no significant association between them. Rodríguez Domínguez \& Gámez (2014) reported an inverse relationship between the amount of risk disclosure and company size. Despite these mixed results, we put forward our first set of three hypotheses about the level of company size and risk disclosure. 
Hypothesis H1a (H1a): There is a positive association between company size and the total number of risk disclosures.

Hypothesis H1b (H1b): There is a positive association between company size and the total number of financial risk disclosures.

Hypothesis H1c (H1c): There is a positive association between company size and the total number of non-financial risk disclosures.

\subsection{Level of risk}

As per Linsley \& Shrives (2006) and in accordance with agency theory, it should be noted that companies with greater risk levels would prefer to close less information on risks because the directors need to clarify the reasons behind the company's higher risk. However, some of the directors are unwilling to share their riskiness (Linsley \& Shrives, 2006). Thus, the association between the level of risk disclosure and company risk is considered null, as we explain next. Relying on the risk management and agency theory, we can expect that there will be a positive link between disclosing risk information and the level of company risk. The early studies offer two opposing views of the linkage between the company level of risk and level of disclosure: positive association (Elshandidy et al., 2013; Taylor et al., 2010), and not significant linkage (Abid \& Shaique, 2015; Alsaeed, 2006; Amran et al., 2008; Dey et al., 2018; Halbouni \& Yasin, 2016; Linsley \& Shrives, 2006). Thus, our second set of three hypotheses about the level of company risk and risk disclosure follows in the null form.

Hypothesis H2a (H2a): There is no association between company risk and the total number of risk disclosures.

Hypothesis H2b (H2b): There is no association between company risk and the total number of financial risk disclosures.

Hypothesis H2c (H2c): There is no association between company risk and the total number of non-financial risk disclosures.

\subsection{Economic sign (monetary/non-monetary)}

The importance of monetary value (quantified estimates) of disclosed risk is essential to increase the quality of risk reporting (Linsley \& Shrives, 2006). According to Frame (2003), the quantifications of risk can be challenging due to data unavailability. However, this situation depends on highly subjective or non-subjective inputs. Linsley \& Shrives (2006) state that directors will be willing to avoid the non-quantification of the proposal based on the non-subjective inputs, because it can draw provocative critical attention, and their empirical findings showed a much greater frequency of non-monetary disclosure. A large body of literature (Abraham \& Shrives, 2014; Linsley \& Shrives, 2006; Ntim et al., 2013) provides support for the tendency mentioned above to highlight a lack of monetary risk information; while in contradiction, the recent study of Marzouk (2016) declared companies disclosed more monetary disclosure than non-monetary. Accordingly, from the majority of studies, the third hypothesis is stated.

Hypothesis H3 (H3): The number of monetary risk disclosures will be considerably lesser than the number of non-monetary risk disclosures. 


\subsection{Type of measure (past/future)}

It has been emphasized that future risk information is more beneficial in the decision-making of stakeholders than past information (Linsley \& Shrives, 2006; Ntim et al., 2013; Marzouk, 2016). It is because the future is uncertain, and the wrong information can mislead the people who relied on them. The results of Ntim et al., (2013) pointed out that past-looking disclosures were more frequent than forward-looking disclosures. Therefore, the hypothesis $\mathrm{H} 4$ is as follows:

Hypothesis H4 (H4): The number of future risk disclosures will be considerably less than the number of past risk disclosures.

\subsection{Outlook sign (good/bad/neutral)}

Commonly, directors do not want to share bad news with external parties (Linsley \& Shrives, 2006), while good news disclosures generate lesser stock price reactions than bad news disclosures (Skinner, 1994). If managers fail to report bad news in a timely manner, reputational losses may be incurred, and stockholders may not follow firms reputed to withhold bad news (Skinner, 1994). Consequently, as depicted in attribution theory, directors can disclose less positive risk information (Marzouk, 2016). Based on agency and legitimacy theories, and resources-based perspectives, managers prioritize disclosing the same level to eliminate asymmetries and foster an impression of pro-activity (Combes-Thuélin et al., 2006). The results showed that the total number of bad and good disclosures were not considerably dissimilar, which odd with prior findings of higher levels of good news disclosures (Linsley \& Shrives, 2006; Marzkouk, 2016; Ntim et al., 2013) or bad news disclosures (Skinner, 1994). This indicates that it is hard to predict the amounts of bad and good risk news. Therefore, the following is hypothesized.

Hypothesis H5 (H5): The number of good and bad risk disclosures will not differ significantly from each other.

\section{RESEARCH OBJECTIVE, METHODOLOGY, AND DATA}

\subsection{Data sample}

The final dataset consists of 34 annual reports of automakers headquartered and listed on security exchanges in ten countries (namely China, France, Germany, Hong Kong, Italy, Japan, Malaysia, South Korea, Taiwan, and the United States), listed within the NASDAQ OMX Global Automobile Index that tracks the performance of the biggest and the most liquid companies engaged in the manufacturing of automobiles worldwide since 2011. The annual reports selected for analysis were those with a year-end date nearest to 1 January 2019, consistently with the Linsley \& Shrives (2006).

\subsection{Variable description}

The level of company size and risk can be measured in several ways. In this study, to test the hypotheses, the level of company size and the company level of risk need to be measured. Turnover and market value have been selected to measure the level of company size in this paper. Turnover has been sourced directly from the annual report as of 31. 12. 2018. The market value has been 
sourced from Yahoo Finance (2019). The natural logarithm of these three variables mentioned above was taken due to nonlinearity (Abid \& Shaique, 2015; Abraham \& Cox, 2007, Dey et al., 2018; Linsley \& Shrives, 2006).

Systematic risk (3Y monthly beta) and stock volatility (3Y monthly standard deviation) of the company were selected to measure the level of company risk. The systematic risk (3Y monthly beta) was sourced from Yahoo Finance (2019), and stock volatility was calculated using monthly company market prices, in line sourced from Yahoo Finance (2019). Beta measures systematic risk of a company and is calculated by estimating the company's market price volatility relative to the stock market index. Statistically described, beta represents a line slope by regressing data points from the returns of an individual stock against those of the market. A beta of 1 indicates that the company's stock price moves in line with the market, the beta of less than one means that the company is less risky than the stock market, and a beta of greater than one indicates that the company is riskier than the stock market. Companies with low beta do not rise and fall as much as the market, while high beta companies tend to behave opposite, which means they are more volatile. Beta in this paper is the 36 months' average of a monthly change in a company's price compared to the monthly price change of the market. Stock volatility of the company is an average of 36 months of quarterly standard deviations of company market price returns.

\subsection{Methods}

This risk disclosure study aims to examine the risk reporting practices of automakers to answer the calls for more risk reporting and industry-specific risk disclosure studies.

To test the main hypotheses derived in the literature review section, we conducted the following procedure. We applied content analysis that is considered to be a widely used method for analyzing disclosures in accounting research (Abid \& Shaique, 2015) in this empirical study. In line with Linsley \& Shrives (2006) i) the sentence has been judged to be a risk disclosure in the annual report if the coder is informed of any opportunity or prospect, or of any hazard, danger, harm, threat or exposure, that has already impacted upon the company or may impact upon the company in the future or of the management of any opportunity, prospect, hazard, harm, threat or exposure ii) and have been categorized and counted in six risk categories, namely financial risks, operations risks, integrity risk, information processing and technology risks, strategic risks, and empowerment risk (Table 1), by performing ex-post manual content analysis. Furthermore, we used Pearson correlation and Wilcoxon signed ranks (advocated as adequate practical methods, inter alia, by the closest study to ours of Linsley \& Shrives, 2006) to empirically test the set hypotheses related to the firm's risk reporting practices. The Wilcoxon signed rank test is a nonparametric test used to compare two dependent samples when the differences between these two pairs of data are assumed to be non-normally distributed. In addition, non-parametric tests are more intuitive and simpler to calculate by hand when the sample size is small. We employed nonparametric test because the assumption required for parametric tests (e. g. Normality of the data) are not valid. It should be noted that with a small sample size, normality test can have insufficient statistical power to provide useful results. Therefore, the dataset for our study is also regarded as a small sample for the parametric tests, and consequently non-parametric tests were utilized. 


\section{RESULTS AND DISCUSSION}

\subsection{Descriptive statistics}

In the annual reports, a total of 986 risk disclosure sentences were recognized (Table 1). Table 1 shows the classifications and features of the sentences that clarify the risk disclosure. The three risk classifications with the highest number of disclosures are financial risk (289 disclosures), strategic risk (257 disclosures), and operation risk (248 disclosures). Additionally, the other three risk classifications are information processing and technology, empowerment, and integrity risk disclosure, containing 104, 54, and 34 disclosures, respectively.

Tab. 1 - Risk disclosures for sample companies. Source: own research

\begin{tabular}{|c|c|c|c|c|c|c|c|c|c|}
\hline & \multirow[b]{2}{*}{ 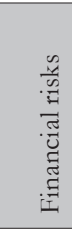 } & \multicolumn{4}{|c|}{ Non-financial risks } & \multirow[b]{2}{*}{$\begin{array}{l}\text { Strate- } \\
\text { gic risks }\end{array}$} & \multirow[b]{2}{*}{ Total } & \multirow[b]{2}{*}{$\begin{array}{l}\text { Pro- } \\
\text { por- } \\
\text { tion } \\
(\%)\end{array}$} \\
\hline & & & $\begin{array}{l}\text { Ope- } \\
\text { ration } \\
\text { risks }\end{array}$ & $\begin{array}{l}\text { Em- } \\
\text { power- } \\
\text { ment } \\
\text { risks }\end{array}$ & $\begin{array}{l}\text { Informati- } \\
\text { on proces- } \\
\text { sing and } \\
\text { technology } \\
\text { risks }\end{array}$ & $\begin{array}{l}\text { Integri- } \\
\text { ty risks }\end{array}$ & & & \\
\hline $\begin{array}{l}\text { Risk Disclosure Sen- } \\
\text { tence Characteristics }\end{array}$ & & 1 & 2 & 3 & 4 & 5 & 6 & & \\
\hline $\begin{array}{l}\text { Monetary/good news/ } \\
\text { future }\end{array}$ & A & 24 & 9 & 8 & 2 & 1 & 13 & 57 & 5.8 \\
\hline $\begin{array}{l}\text { Monetary/bad news/ } \\
\text { future }\end{array}$ & B & 68 & 41 & 3 & 6 & 5 & 33 & 156 & 15.8 \\
\hline $\begin{array}{l}\text { Monetary/neutral/ } \\
\text { future }\end{array}$ & $\mathrm{C}$ & 72 & 13 & 4 & 4 & 5 & 11 & 109 & 11.1 \\
\hline $\begin{array}{l}\text { Non-monetary/good } \\
\text { news/future }\end{array}$ & $\mathrm{D}$ & 18 & 30 & 8 & 17 & 5 & 26 & 104 & 10.5 \\
\hline $\begin{array}{l}\text { Non-monetary/bad } \\
\text { news/future }\end{array}$ & $\mathrm{E}$ & 17 & 52 & 3 & 25 & 9 & 77 & 183 & 18.6 \\
\hline $\begin{array}{l}\text { Non-monetary/neut- } \\
\mathrm{ral} / \text { future }\end{array}$ & $\mathrm{F}$ & 37 & 50 & 14 & 24 & 3 & 59 & 187 & 19.0 \\
\hline $\begin{array}{l}\text { Monetary/good news/ } \\
\text { past }\end{array}$ & G & 11 & 6 & 5 & 1 & 0 & 1 & 24 & 2.4 \\
\hline $\begin{array}{l}\text { Monetary/bad news/ } \\
\text { past }\end{array}$ & $\mathrm{H}$ & 11 & 16 & 0 & 0 & 1 & 5 & 33 & 3.3 \\
\hline Monetary/neutral/past & I & 10 & 5 & 0 & 0 & 0 & 2 & 17 & 1.7 \\
\hline $\begin{array}{l}\text { Non-monetary/good } \\
\text { news/past }\end{array}$ & $\mathrm{J}$ & 0 & 5 & 3 & 4 & 3 & 9 & 24 & 2.4 \\
\hline $\begin{array}{l}\text { Non-monetary/bad } \\
\text { news/past }\end{array}$ & K & 0 & 9 & 0 & 1 & 2 & 7 & 19 & 1.9 \\
\hline $\begin{array}{l}\text { Non-monetary/neut- } \\
\mathrm{ral} / \mathrm{past}\end{array}$ & $\mathrm{L}$ & 3 & 8 & 1 & 5 & 0 & 5 & 22 & 2.2 \\
\hline Sub-total & & 271 & 244 & 49 & 89 & 34 & 248 & 935 & \\
\hline
\end{tabular}




\begin{tabular}{|l|l|l|l|l|l|l|l|l|l|}
\hline $\begin{array}{l}\text { Non-monetary/neut- } \\
\text { ral/non-time specific } \\
\text { statements of risk ma- } \\
\text { nagement policy }\end{array}$ & $\mathrm{M}$ & 18 & 4 & 5 & 15 & 0 & 9 & 51 & 5.2 \\
\hline Total & 289 & 248 & 54 & 104 & 34 & 257 & 986 & 100 \\
\hline Proportion & $29.3 \%$ & $25.2 \%$ & $5.5 \%$ & $10.5 \%$ & $3.4 \%$ & $26.1 \%$ & $100 \%$ & \\
\hline
\end{tabular}

Descriptive statistics are reported in Table 2. The sample sizes for the total, financial, and nonfinancial risk disclosure sentences are 986, 289, and 697, respectively. Table 2 shows that the mean total risk disclosure rate per report is 29 sentences. The variation in the number of total risk disclosures is relatively large, which is in the same line with Linsley \& Shrives (2006) study, ranging from a minimum of 6 sentences to a maximum of 183 sentences. In our sample, a Chinese company's total risk disclosure had the lowest rate (6 sentences), and a U.S. company's total risk disclosure had the highest rate (183 sentences). In addition, the mean value for the financial disclosure rate per report (about nine sentences) is lower than the non-financial disclosure rate per report (about 21 sentences). The range of non-financial disclosures is also relatively wide, from a low of 1 sentence in a U.S. company to a high of 164 sentences in a U.S. company. However, the variation in the number of financial risk disclosures is relatively small, ranging from the lowest financial risk disclosure rate per a report in Japan (1 sentence) to the highest financial risk disclosure rate per a report in Japan (31 sentences).

Tab. 2 - Descriptive statistics. Source: own research

\begin{tabular}{|c|c|c|c|c|c|}
\hline & $\begin{array}{l}\text { Total dis- } \\
\text { closure }\end{array}$ & Minimum & Maximum & Mean & SD \\
\hline Total number of risk disclosures & 986 & 6 & 183 & 29.00 & 32.09 \\
\hline Number of financial disclosures & 289 & 1 & 31 & 8.50 & 6.23 \\
\hline \multirow[t]{2}{*}{$\begin{array}{l}\text { Number of non-financial disclo- } \\
\text { sures }\end{array}$} & 697 & 1 & 164 & 20.50 & 28.61 \\
\hline & 986 & & & & \\
\hline $\begin{array}{l}\text { Number of monetary risk disclo- } \\
\text { sures }\end{array}$ & 396 & 0 & 27 & 11.65 & 6.18 \\
\hline \multirow[t]{2}{*}{$\begin{array}{l}\text { Number of non-monetary risk } \\
\text { disclosures }\end{array}$} & 590 & 0 & 183 & 17.35 & 33.93 \\
\hline & 986 & & & & \\
\hline Number of past risk disclosures & 139 & 0 & 15 & 4.09 & 3.99 \\
\hline Number of future risk disclosures & 796 & 5 & 180 & 23.41 & 30.63 \\
\hline \multirow[t]{2}{*}{$\begin{array}{l}\text { Number of non-time specific risk } \\
\text { management policy disclosures }\end{array}$} & 51 & 0 & 21 & 1.50 & 4.45 \\
\hline & 986 & & & & \\
\hline
\end{tabular}




\begin{tabular}{|l|l|l|l|l|l|}
\hline \multicolumn{2}{|l|}{} \\
\hline Number of good news disclosures & 209 & 0 & 48 & 6.15 & 9.27 \\
\hline Number of bad news disclosures & 391 & 0 & 112 & 11.50 & 18.93 \\
\hline $\begin{array}{l}\text { Number of neutral news disclo- } \\
\text { sures }\end{array}$ & 386 & 0 & 69 & 11.35 & 13.50 \\
\hline & 986 & & & & \\
\hline \multicolumn{7}{|l|}{} & -0.69 & 5.25 & 2.45 & 1.39 \\
\hline Nat log of market capitalization & -2.41 & 5.62 & 2.88 & 1.87 \\
\hline Nat log of turnover & -0.09 & 1.93 & 1.09 & 0.46 \\
\hline Beta factor & & 0.01 & 0.25 & 0.11 & 0.05 \\
\hline Stock volatility & & & & \\
\hline
\end{tabular}

\subsection{Correlation Analysis}

\section{Hypothesis 1 Examination}

To test the first set of hypotheses, the first three rows of Table 3 contain Pearson correlations between the first main variables of interest, especially the level of relationship between the number of risk disclosures and the independent variable of size (company size). The correlation coefficients for the measures of size, the natural log of market value, and the natural log of turnover, indicate that no significant association exists between company size and the number of total risk disclosures, the number of financial risk disclosures, and the number of non-financial risk disclosures.

Tab. 3 - Pearson correlation coefficients for variables. Source: own research

\begin{tabular}{|l|l|l|l|}
\hline Variable & $\begin{array}{l}\text { Total number of } \\
\text { risk disclosures }\end{array}$ & $\begin{array}{l}\text { Total number of finan- } \\
\text { cial risk disclosures }\end{array}$ & $\begin{array}{l}\text { Total number of non- } \\
\text { financial disclosures }\end{array}$ \\
\hline $\begin{array}{l}\text { Nat log of market } \\
\text { cap }\end{array}$ & 0.075 & 0.179 & Pearson correlation \\
\hline Nat log of turnover & 0.059 & 0.058 & 0.046 \\
\hline Beta factor & 0.0147 & $-0.332^{*}$ & 0.054 \\
\hline Stock volatility & $-0.311^{*}$ & -0.140 & 0.089 \\
\hline
\end{tabular}

* Correlation is significant at the 0.10 level

With regard to the first hypothesis, we found out that there was no correlation noted for company size and the volume of risk disclosure. The findings of the current study do not reflect the findings of previous studies (Abid \& Shaique, 2015; Abraham \& Cox, 2007; Alsaeed, 2006; Amran et al., 2008; Dey et al., 2018; Elshandidy \& Shrives 2016; Elshandidy et al., 2013; Elzahar \& Hussainey, 2012; Linsley \& Shrives, 2006; Marzouk, 2016; Miihkinen, 2012; Taylor et al., 2010; Rodríguez Domínguez \& Gámez, 2014), at least, from the automotive industry perspective. Our findings highlighted that the size of the company in the automotive industry does not play a 
significant role in explaining the number of total, financial, and non-financial risk disclosures, which is in the same line with the studies of Halbouni \& Yasin (2016). Therefore, we maintain that larger companies do not disclose more risk information to manage stakeholders' perceptions about corporate reputation, as is suggested by legitimacy theory and resources-based perspective adopted in developing the first hypothesis.

\section{Hypothesis 2 Examination}

To test the second set of hypotheses, the last two rows of Table 3 comprise Pearson correlations between the second main variables of interest, especially the relationship between the number of risk disclosures and the independent variable of the level of risk. The correlation coefficients for the beta factor show no significant association between risk measures, the number of total risk disclosures, and the number of non-financial risk disclosures. The beta factor is negatively correlated with the number of financial risk disclosures $(r=-0.332 ; \mathrm{p}<0.10)$. The negative correlation between the beta factor and the number of financial risk disclosures implies that companies with higher levels of systematic risk are closing greater volumes of financial risk information. The correlation coefficients for stock volatility are significantly correlated with the number of total $(\mathrm{r}$ $=-0.311 ; \mathrm{p}<0.10)$ and non-financial $(\mathrm{r}=-0.318 ; \mathrm{p}<0.10)$ risk disclosures, except for financial risk disclosures. The negative correlation between the stock volatility and the number of total and non-financial risk disclosures indicates that companies with higher levels of risk are closing greater volumes of total and non-financial risk information.

\subsection{Wilcoxon Signed Ranks Test}

To examine Hypotheses 3-5, Wilcoxon signed rank tests were employed (Table 4).

Tab. 4 - Wilcoxon signed rank test results. Source: own research

\begin{tabular}{|c|c|c|c|c|}
\hline & & $\mathrm{N}$ & Mean rank & Sum of ranks \\
\hline \multirow[t]{4}{*}{$\begin{array}{l}\text { Non-monetary- } \\
\text { monetary }\end{array}$} & Negative ranks (a) & 14 & 15.64 & 219 \\
\hline & Positive ranks (b) & 20 & 18.80 & 376 \\
\hline & Ties & 0 & & \\
\hline & Total & 34 & & \\
\hline \multirow[t]{4}{*}{ Past-future } & Negative ranks (c) & 33 & 17.82 & 588 \\
\hline & Positive ranks (d) & 1 & 7 & 7 \\
\hline & Ties & 0 & & \\
\hline & Total & 34 & & \\
\hline \multirow[t]{4}{*}{ Bad-good } & Negative ranks (e) & 11 & 14.09 & 155 \\
\hline & Positive ranks (f) & 23 & 19.13 & 440 \\
\hline & Ties & 0 & & \\
\hline & Total & 34 & & \\
\hline
\end{tabular}




\begin{tabular}{|c|c|c|c|}
\hline Test statistic & & & \\
\hline & Non-monetary-monetary & Past-future & Bad-good \\
\hline $\mathrm{Z}$ & -1.343 & -4.968 & 2.439 \\
\hline Asymp. Sig. & 0.171 & 0.000 & 0.015 \\
\hline
\end{tabular}

(a) Number of companies with monetary risk disclosures greater than non-monetary risk disclosures.

(b) Number of companies with non-monetary risk disclosures greater than monetary risk disclosures.

(c) Number of companies with future risk disclosures greater than past risk disclosures.

(d) Number of companies with past risk disclosures greater than future risk disclosures.

(e) Number of companies with good risk disclosures greater than bad risk disclosures.

(f) Number of companies with bad risk disclosures greater than good risk disclosures.

Regarding the second hypothesis, we determined that the relationship between company risk and risk disclosure is negatively associated, and consequently we do not support the idea that riskier companies disclose more risk information as suggested by agency theory as well as prior literature (Elshandidy et al., 2013; Taylor et al., 2010). Against this background, ours is the first study that confirms the negative association between the level of company risk and risk disclosure, and thus our results go against the conventional wisdom that non-financial companies with higher levels of risk disclose greater volumes of risk information. This result was robust and confirmed using both beta and stock volatility, factors which successfully addresses the issues related to risk disclosure. Both risk measures indicate the same negative sign.

A number of significant implications emerge from this evidence. Companies with higher systematic risk in the automotive industry are prone to disclose a greater amount of financial risk information (Table 3). This could be explained by the idea that companies with a higher level of risk have an incentive not to disclose financial risk information, as they may be subsequently required to justify their prior estimates. This may leave them vulnerable to litigation and, thus, a concealing motive prevails.

Additionally, the higher stock volatility of companies in the automotive industry can lead them to disclose more total and non-financial risk information. This may also lend support to the impression management argument or legitimacy theory since the results of the current study reveal that the riskier companies for stockholders disclose less, implying management potentially manipulates risk reporting by the omission of information (less complex reporting) to affect the risk perceptions of investors.

\section{Examination of Hypothesis 3}

In testing Hypothesis 3, the number of positive ranks is 20 , with the number of negative ranks 14 (Table 4). However, the Wilcoxon test results do not support Hypothesis 3 due to the insignificant $\mathrm{p}$-value of 0.171 . This shows that despite the number of non-monetary risk disclosures surpassing the number of monetary disclosures for all companies sampled in the current study, its results cannot be considered statistically significant.

According to the third hypothesis, we found the same sign as previous studies (Abraham \& Shrives, 2014; Linsley \& Shrives, 2006; Ntim et al., 2013). These studies indicate that monetary 
risk disclosure will be considerably less than the amount of non-monetary risk disclosure. However, these results were not statistically significant.

\section{Examination of Hypothesis 4}

The results of the Wilcoxon test do not support Hypothesis 4. Here the opposite is the case, as the number of future risk disclosures is significantly greater than the amount of past risk disclosure (Table 4). It can be seen that the number of negative ranks is 33 , and the number of positive ranks is 1 . The significance value of 0.000 implies strong support for this reverse case.

Regarding the fourth hypothesis, the findings reveal a reverse relation: future risk disclosures are significantly higher than those of past risk disclosures. There are possible explanations for this result; one of the key fundamental explanations stems from the idea that shareholders and stakeholders in the automotive industry may require companies to disclose information concerning their future predictions, as the economic environment is considered dynamic and thus they cannot rely on past information (K1lıç \& Kuzey; 2018).

\section{Examination of Hypothesis 5}

The Wilcoxon test results do not support Hypothesis 5, i.e. that there would not be a significant difference between good and bad risk disclosures. There is strong support for the difference between bad and good risk disclosures $(\mathrm{p}=0.015)$, by which 23 companies disclosed a higher number of bad risk disclosures, compared to 11 companies that disclosed more good risk disclosures (Table 4).

We again found reverse results regarding the fifth hypothesis which show a significant difference between bad and good risk disclosure in the automotive industry. This idea stems from the attribution theory, i.e. that directors in the automotive industry convey bad news to third parties, particularly when discussing bad risk news.

Table 5 shows a summary of the previously described outcomes of hypothesis testing (see Appendix A).

\section{CONCLUSION}

Prior research has declared that increased corporate transparency facilitates firm competitiveness (Wyld, 2009; Shivaani \& Agarwal, 2020). In other words, firm-specific information revealed to the public helps make enterprises more competitive. Wyld (2009) indicates that less transparent firms have lower growth rates, lower investment efficiency, and higher capital costs. Furthermore, less transparent firms provide less informed choices for shareholders. Enhanced transparency alerts stakeholders that a business aiming to acquire a competitive position continues to maintain its ethical standards (Shivaani \& Agarwal, 2020). Despite a substantial increase in risk reporting studies in recent years as well as significant interest in a wide range of user groups, the corporate transparency phenomenon in terms of risk disclosures is still very much in its infancy (Abraham \& Shrives, 2014).

This study examines the level and context of risk disclosure of publicly traded automotive companies by investigating the association between the level of risk disclosure and firm-specific charac- 
teristics (company size and company risk), as well as exploring the risk disclosure characteristics (namely, type of risk, time orientation, and proportion of good and bad risk disclosure). In its examinations of the risk reporting practices of non-financial companies using textual analysis, our work seeks to extend in several ways research in mainstream financial accounting. First, our cross-country, single-industry (automotive) study addresses the lack in the literature regarding industry-specific risk, cross-country, and automotive industry-based disclosure studies. Second, our findings in terms of the relationship between the level of risk disclosure and company level of size/risk can help develop further hypotheses which can shed some more light on the question of whether larger and more volatile listed companies reveal more risk information. Finally, our explanation of the prevalent disclosure context can serve policymakers, academicians, and users of annual reports to reach a deeper understanding of the phenomenon of current risk reporting practices of non-financial companies, as well as the limits and usefulness of risk disclosure.

This study presents some limitations that could be overcome by further studies. We here focus on annual reports; for deeper and more enhanced research it would be useful to gather and evaluate other evidence in supplementary documents such as corporate press releases, websites, prospectuses and presentations. Additionally, the Wilcoxon signed rank test that we employed in our study has a noticeable disadvantage in that it disregards the magnitude of the observations measured. While it distributes a sign to each observation to indicate whether it remains the below or above hypothesized value, this does not account for scale or significance. The statistical power of the Wilcoxon signed rank test is thus limited, and further studies should focus on more parametric methods. Another limit of our research which might be addressed in future investigations is that our work here does not represent a longitudinal study. Further studies could apply automated content analysis as well as explore the risk reporting practices of listed non-financial companies in a longitudinal framework using a greater number of proxies to focus on information and agency problems. Moreover, studies might evaluate the effects of risk reporting practices on user risk perceptions of financial information. Other research projects might attempt to explore the motivations for both voluntary and mandatory risk disclosure in non-financial listed companies. Each of these potential tracks could in their own way contribute to a more complete understanding of information content and risk factor disclosure.

\section{Acknowledgment}

This research was funded by the Czech Science Foundation under the Grant No. 16-25536S and by the Internal Grant Agency of Tomas Bata University in Zlín under the Grant No. IGA/ FaME/2019/003.

\section{References}

1. Abid, A., \& Shaique, M. (2015). A study of risk disclosure in the annual reports of Pakistani companies: A Content Analysis. Research Journal of Finance and Accounting, 6 (11), 14-24.

2. Abraham, S., \& Cox, P. (2007). Analysing the determinants of narrative risk information in UK FTSE 100 annual reports. The British Accounting Review, 39 (3), 227-248.

https://doi.org:/10.1016/j.bar.2007.06.002 
3. Abraham, S., \& Shrives P. J. (2014). Improving the relevance of risk factor disclosure in corporate annual reports. The British Accounting Review, 46 (1), 91-107. https://doi.org:/doi.org/10.1016/j.bar.2013.10.002

4. Alsaeed, K. (2006). The association between firm-specific characteristics and disclosure. Managerial Auditing Journal, 21 (5), 476-496. https://doi.org:/10.1108/02686900610667256

5. Amran, A., Manaf Rosli Bin, A., \& Che Haat Mohd Hassan, B. (2008). Risk reporting. Managerial Auditing Journal, 24, 39-57. https://doi.org:/10.1108/02686900910919893

6. Badia, M., Barth, M. E., Duro, M. \& Ormazabal, G. (2019). Firm risk and disclosures about dispersion of asset values: Evidence from oil and gas reserves. The Accounting Review, 95 (1), 1-29. https://doi.org:/10.2308/accr-52445

7. Bae, S. M., Masud, M., Kaium, A. \& Kim, J. D. (2018). A cross-country investigation of corporate governance and corporate sustainability disclosure: A signaling theory perspective. Sustainability, 10 (8), 2611. https://doi.org:/10.3390/su10082611

8. Bao, Y., \& Datta, A. (2014). Simultaneously discovering and quantifying risk types from textual risk disclosure. Management Science, 60 (6), 1371-1391. https://doi.org:/10.1287/mnsc.2014.1930

9. Camfferman, K., \& Wielhouwer, J. L. (2019). 21st century scandals: towards a risk approach to financial reporting scandals. Accounting and Business Research, 49 (5), 503-535. https://doi.org:/10.1080/00014788.2019.1614267

10. Campbell, J. L., Chen, H., Dhaliwal, D. S., Lu, H., \& Steele, L. B. (2014). The information content of mandatory risk factor disclosure in corporate filings. Review of Accounting Studies, 19, 396-455. https://doi.org:/10.1007/s11142-013-9258-3

11. Campbell, J. L., Cecchini, M., Cianci, A. M., Ehinger, A. C., \& Werner, E. M. (2019). Taxrelated mandatory risk factor disclosures, future profitability, and stock returns. Review of Accounting Studies, 24, 264-308. https://doi.org:/10.1007/s11142-018-9474-y

12. Chiu, T.-T., Guan, Y., \& Kim, J.-B. (2018). The effect of risk factor disclosure on the pricing of credit default swaps. Contemporary Accounting Research, 35 (4), 2191-2224.

https://doi.org:/10.1111/1911-3846.12362

13. Combes-Thuélin, E., Henneron, S., \& Touron, P. (2006). Risk regulations and financial disclosure. Corporate communications: An International Journal, 11 (3), 303-326. https://doi.org:/10.1108/13563280610680876

14. Dey, R., Hossain, S., \& Rezaee, Z. (2018). Financial risk disclosure and financial attributes among publicly traded manufacturing companies: Evidence from Bangladesh. Journal of Riske and Financial Management, 11 (3), 1-16. https://doi.org:/10.3390/jrfm11030050

15. Elshandidy, T., \& Neri, L. (2015). Corporate governance, risk disclosure practices, and market liquidity: Comparative evidence from the U.K. and Italy. Corporate Governance: An International Review, 23 (4), 331-356. https://doi.org/10.1111/corg.12095

16. Elshandidy, T., \& Shrives, P. J. (2016). Environmental incentives for and usefulness of textual risk reporting: Evidence from Germany. The International Journal of Accounting, 51 (4), 464-486. https://doi.org:/10.1016/j.intacc.2016.10.001 
17. Elshandidy, T., Fraser, I., \& Hussainey, K. (2013). Aggregated, voluntary, and mandatory risk disclosure incentives: Evidence from UK FTSE all-share companies. International Review of Financial Analysis, 30, 320-333. https://doi.org:/10.1016/j.irfa.2013.07.010

18. Elshandidy, T., Shrives, P. J., Bamber, M., \& Abraham, S. (2018). Risk reporting: A review of the literature and implications for future research. Journal of Accounting Literature, 40, 54-82. https://doi.org:/10.1016/j.acclit.2017.12.001

19. Elzahar, H., \& Hussainey, K. (2012). Determinants of narrative risk disclosure in U.K. interim reports. The Journal of Risk Finance, 13 (2), 133-147. https://doi.org:/10.1108/15265941211203189

20. Filzen, J. J. (2015). The information content of risk factor disclosure in quarterly reports. Accounting Horizons, 29 (4), 887-916. https://doi.org:/10.2308/acch-51175

21. Frame, J. D. (2003). Managing Risk in Organizations. San Francisco: Josey-Bass.

22. Gavana, G., Gottardo, P., \& Moisello, A. M. (2017). Sustainability reporting in family firms: A panel data analysis. Sustainability, 9 (1), 38. https://doi.org:/10.3390/su9010038

23. Halbouni, S. S., \& Yasin, A. (2016). Risk disclosure: Empirical investigation of UAE companies' compliance with International Accounting Standards. International Journal of Business and Management, 11 (8), 134-144. https://doi.org:/10.5539/ijbm.v11n8p134

24. Hassan, O. A., Giorgioni, G., \& Romilly, P. (2006). The extent of financial disclosure and its determinants in an emerging capital market: the case of Egypt. International Journal of Accounting Auditing and Performance Evaluation, 3 (1), 41-67. https://doi.org:/10.1504/ijaape.2006.010102

25. Hill, P., \& Short, H. (2009). Risk disclosure on the second tier markets of the London Stock Exchange. Accounting and Finance, 49 (4), 753-780. https://doi.org:/10.1111/j.1467-629x.2009.00308.x

26. Hope, O. K., Hu, D., \& Lu, H. (2016). The benefits of specific risk-factor disclosure. Review of Accounting Studies, 21, 1005-1045. https://doi.org:/10.1007/s11142-016-9371-1

27. Jensen, M. C., \& Meckling, W. H. (1976). Theory of the firm: Managerial behavior, agency costs and ownership structure. Journal of Financial Economics, 3 (4), 305-360. https://doi.org:/10.1016/0304-405x(76).90026-x.

28. International Monetary Fund. (2019). World Economic Outlook. Washington, DC: International Monetary Fund.

29. Kang, H., \& Gray, S. J. (2019). Country-specific risks and geographic disclosure aggregation: Voluntary disclosure behaviour by British multinationals. The British Accounting Review, 51 (3), 259-276. https://doi.org:/10.1016/j.bar.2019.02.001

30. Kilıç, M., \& Kuzey, C. (2018). Determinants of forward-looking disclosures in integrated reporting. Managerial Auditing Journal, 33 (1), 115-144.

https://doi.org/10.1108/MAJ-12-2016-1498

31. Kim, H., \& Yasuda, Y. (2018). Business risk disclosure and firm risk: Evidence from Japan. Research in International Business and Finance, 45, 413-426. https://doi.org:/10.1016/j.ribaf.2017.07.172

32. Kravet, T., \& Muslu, V. (2013). Textual risk disclosure and investors' risk perceptions. Review of Accounting Studies, 18, 1088-1122. https://doi.org:/10.1007/s11142-013-9228-9 
33. Kurniawanto, H., Suhardjanto, D., \& Agustiningsih, S. W. (2017). Corporate governance and corporate risk disclosure: Empirical evidence of non-financial companies listed in Indonesia stock exchange. Review of Integrative Business and Economics Research, 6 (4), 255-270.

34. Linsley, P. M., \& Lawrence, M. J. (2007). Risk reporting by the largest U.K. companies: readability and lack of obfuscation. Accounting, Auditing and Accountability Journal, 20 (4), 620-627. https://doi.org:/10.1108/09513570710762601

35. Linsley, P. M., \& Shrives, P. J. (2006). Risk reporting: A study of risk disclosure in the annual reports of U.K. companies. The British Accounting Review, 38 (4), 387-404. https://doi.org/10.1016/j.bar.2006.05.002

36. Lobo, G. J., Siqueira, W. Z., Tam, K., \& Zhou, J. (2019). Does SEC FRR No. 48 disclosure communicate risk management effectiveness? Journal of Accounting and Public Policy, 38 (6), 106696. https://doi.org:/10.1016/j.jaccpubpol.2019.106696

37. Manes-Rossi, F., Tiron-Tudor, A., Nicolò, G., \& Zanellato, G. (2018). Ensuring more sustainable reporting in Europe using non-financial disclosure-De facto and de jure evidence. Sustainability. 10 (4), 1162. https://doi.org/10.3390/su10041162

38. Marzouk, M. (2016). Risk reporting during a crisis: evidence from the Egyptian capital market. Journal of Applied Accounting Research, 17 (4), 378-396. https://doi.org:/10.1108/jaar-02-2015-0012

39. Miihkinen, A. (2012). What Drives Quality of Firm Risk Disclosure? The International Journal of Accounting, 47 (4), 437-468. https://doi.org:/10.1016/j.intacc.2012.10.005

40. Nadirov, O., Vychytilová, J., \& Dehning, B. (2020). Carbon Taxes and the Composition of New Passenger Car Sales in Europe. Energies, 13 (18), 4631.

https://doi.org/10.3390/en13184631

41. Ntim, C. G., Lindop, S., \& Thomas, D. A. (2013). Corporate governance and risk reporting in South Africa: A study of corporate risk disclosure in the pre- and post-2007/2008 global financial crisis periods. International Review of Financial Analysis, 30, 363-383. https://doi.org:/10.1016/j.irfa.2013.07.001

42. Pivac, S., Vuko, T., \& Cular, M. (2017). Analysis of annual report disclosure quality for listed companies in transition countries. Economic Research-Ekonomska Istrą̌ivanja, 30 (1), 721-731. https://doi.org:/10.1080/1331677x.2017.1311231

43. Rodríguez Domínguez, L., \& Gámez, L. C. (2014). Corporate reporting on risks: Evidence from Spanish companies. Revista de Contabilidad, 17 (2), 116-129.

https://doi.org:/10.1016/j.rcsar.2013.10.002 is

44. Shivaani, M. V., \& Agarwal, N. (2020). Does competitive position of a firm affect the quality of risk disclosure? Pacific-Basin Finance Journal, 61, 101317. https://doi.org:/10.1016/j.pacfin.2020.101317

45. Shocker, A. D., \& Sethi, S. P. (1973). An Approach to incorporating societal preferences in developing corporate action strategies. California Management Review, 15 (4), 97-105. https://doi.org:/10.2307/41164466

46. Skinner, D. J. (1994). Why firms voluntarily disclose bad news. Journal of Accounting Research, 32 (1), 38-60. https://doi.org:/10.2307/2491386 
47. Spence, M. (1973). Job Market Signaling. The Quarterly Journal of Economics, 87 (3), 355-374. https://doi.org:/10.2307/1882010

48. Taylor, G., Tower, G., \& Neilson, J. (2010). Corporate communication of financial risk. Accounting and Finance, 50 (2), 417-446. https://doi.org:/10.1111/j.1467-629x.2009.00326.x

49. Transparency International. (2014). Transparency in corporate reporting: Assessing the world's largest companies. https://www.transparency.org/whatwedo/publication/transparency_in_ corporate_reporting_assessing_worlds_largest_companies_2014

50. Vychytilová, J., Pavelková, D., Pham, H., \& Urbánek, T. (2019). Macroeconomic factors explaining stock volatility: multi-country empirical evidence from the auto industry. Journal of Economic Research-Ekonomska Istraživanja, 32 (1), 3327-3341. https://doi.org/10.1080/1331677X.2019.1661003

51. Watts, R., \& J. Zimmerman. (1978). Towards a positive theory of the determination of accounting standards. The Accounting Review, 53 (1), 112-134.

52. World Bank (2019). Transport. https://www.worldbank.org/en/topic/transport

53. Wyld, C.D. (2009). Is Transparency Critical for Firm and National Competitiveness? Academy of Management Perspectives, 23 (4), 94-96. https://doi.org/10.5465/amp.23.4.94

\section{Contact information}

Ing. Jana Vychytilova, Ph.D.

Tomas Bata University in Zlin

Faculty of Management and Economics

Department of Finance and Accounting

Czech Republic

E-mail:vychytilova@utb.cz.

ORCID: 0000-0003-0204-187X

Orkhan Nadirov, Ph.D.

ADA University

School of Public and International Affairs

Azerbaijan

E-mail:onadirov@ada.edu.ar.

ORCID: 0000-0003-0978-1387

Prof. Dr. Ing. Drahomira Pavelkova

Tomas Bata University in Zlin

Faculty of Management and Economics

Department of Finance and Accounting

Crech Republic

E-mail:pavelkova@utb.cr.

ORCID: 0000-0003-1399-6129
Ing. Martin Mikeska, Ph.D.

Tomas Bata University in Zlin

Faculty of Management and Economics

Department of Economics

Czech Republic

E-mail:mikeska@utb.cr.

ORCID: 0000-0001-7467-0793 


\section{Appendix A}

Tab. 5 - Summary of outcomes of hypothesis testing. Source: own research

\begin{tabular}{|l|l|l|}
\hline Hypothesis & \multicolumn{1}{|c|}{$\begin{array}{l}\text { Company size-number of risk disclosure association (size- } \\
\text { effect) }\end{array}$} & No association \\
\hline H1 & $\begin{array}{l}\text { Company risk level-number of risk disclosure association } \\
\text { (risk-effect) }\end{array}$ & Indeterminate \\
\hline H3 & $\begin{array}{l}\text { Monetary risk disclosure will be significantly lesser than } \\
\text { non-monetary risk disclosure }\end{array}$ & Not supported \\
\hline H4 & $\begin{array}{l}\text { Future risk disclosure will be significantly lesser than past } \\
\text { risk disclosure }\end{array}$ & Not supported \\
\hline H5 & $\begin{array}{l}\text { Good and bad risk disclosure will not be significantly dis- } \\
\text { similar from each other }\end{array}$ & Not supported \\
\hline
\end{tabular}

